\title{
The Effect of Family, Peer, Behavior, Saving and Spending Behavior on Financial Literacy among Young Generations
}

\author{
Jamal Mohammed Esmail Alekam ${ }^{1 *}$, Madya Salniza Bt Md. Salleh², \\ Sany Sanuri bin Mohd. Mokhtar ${ }^{3}$
}

${ }^{1} \mathrm{PhD}$, Marketing, Senior Lecturer, School of Business Management SBM, University Utara Malaysia UUM, 06010, Sintok, Malaysia

${ }^{2,3}$ School of Business Management, Universiti Utara Malaysia

\section{Keywords:}

Family, Peer, Behavior, Saving and Spending behavior, Influence Financial Literacy

\section{Received}

16 May 2018

Received in revised form 01 September 2018

Accepted

01 September 2018

Correspondence:

jamalalekam@uum.deu.my

\section{ABSTRACT}

Financial literacy has become a significant challenge in society especially among the young generation. Financial literacy is about distinct knowledge, behavior and normative influence towards financial literacy affairs. It will help the youthful generation to make good financial commitment. Financial literacy also involves the distinct ability to understand financial idea and interpret data. Hence, the purpose of this study is to assess the height of financial literacy amid the young generation in Malaysia. It directs to developing a unique representation of financial literacy among youthful age as assumed Family, Peer, Attitude, Saving and spending behavior significantly influence Financial Literacy among Young Generations. Considered relationships were tested using survey response from Kedah, Perlis, Perak, Johor and Kuala Lumpur, with a sample of 500 respondents. About 410 answers from the respondents were received. The questionnaire consisted of 42 items. The results revealed a significant positive relationship between Behavior and Financial Literacy. Furthermore, the findings showed that Family/Parental and Peer significantly influenced Financial Literacy. Hence, this study implies that it is related to the public, academic and university administrators, government, and financial advisor to grow the level of financial literacy by implementing several financial educational programmers. Ultimately, this study is considered one of the studies that have contributed to the literature by developing apprehensions of financial literacy.

The financial literacy has become a major challenge in society, particularly amid young people. Financial literacy is about an individual's awareness, act and normative influence towards 
financial extent. It will help a young generation to make a good financial choice. Financial literacy also involves an individual's ability to understand financial notion and interpret data. According to Remund (2010), financial literacy is more than a measure of awareness where it also reflects competency in actively managing individual or personal finance.

Financial literacy goes beyond the provision of financial information and suggestion. It is referred to the ability to know, monitor, and efficiently use financial sources to enhance the well-being and economic coverage of an individual, family, and businesses. The Organization for Economic Co-operation and Development (OECD) define the financial literacy as - "A combination of awareness, knowledge, skill, attitude and behaviour necessary to make sound financial decisions and ultimately achieve individual financial well-being".

Financial awareness is one of the factors of financial literacy. It is the apprehending of the relationship between inflation and return, interest calculations, risk and return, inflation and prices, and the role of diversification in risk reduction (Sekar \& Gowri, 2015). In order to develop financial planning or financial landscape, financial awareness and minimum basic financial competency are required (Peeters, Rijk, Soetens, Storms, \& Hermans, 2018). Many authors and researchers agreed that being in financially educated society empowers an individual to make a better financial decision.

The factor that influences financial literacy is financial behaviour. It refers to how individuals allocate their money, such as the immediate payment of bills, framing proper planned budgets, monitoring it, and saving habits. The financial behaviour is known to be influenced by financial attitude, which is the opinion of the individual about the belief in financial planning and the inclination towards saving and spending the money (Sekar \& Gowri, 2015).

Family and peers play important roles in influencing individual's financial literacy as a result they influence the knowledge in financial literacy, especially for young generations. Financial literacy is mostly concerned with financial planning, continuing wealth accumulation and having better financial decision making. Nonetheless, people tend to become financially illiterate due to personal problems and lack of awareness. These situations caused inadequate knowledge among the young generations about financial dealings and leave them with inappropriate choices. Hence, the purpose of this study is to examine the financial literacy among young generation.

\section{Problem Statement}

Today's Malaysian young generations are becoming increasingly reckless with their spending habit. They tend to value money less compared to the older generations who are not so much into the materialistic world. As the standard of living in Malaysia has improved noticeably, the young generations are granted with greater liberty to shop and make their own consumption choice as a result Malaysia faced changes in lifestyle and spending trend.

According to Idris, Krishnan, and Azmi (2013), most of today's young generation have a short-term orientation and in a lot of ways are protected from the realities of the real challenges that are happening in the world. This condition is alarming because it will certainly result in the young generations' inability to assess the real condition. This situation is true based on the increase in obtaining credit cards, which caused many issues of bankruptcy due to overspending in credit card usage among the young generation. Apart from that issue, there are 
also evidences of many graduates who have breached the contract of the usage of The National Higher Education Loan Fund (PTPTN), the loan given to students to pursue their higher education. These trends lead to lack of financial security, deterioration of quality of life and creating social problems in the future that can inhibit the process of national development and progress (Idris et al., 2013).

In addition to that, Berita Harian newspaper dated September 16, 2014 reported that nearly 45,000 individuals aged less than 35 years in the country were declared bankrupt since three years ago based on the statistics released by the Department of Insolvency Malaysia (MDI). Unexpectedly, an average of almost 41 individual bankruptcies happened every day due to the failure to fulfill the obligation of credit card payments, medical fees, hire purchase and debt with "Along". Table 1 shows the statistics issued by the MDI. As shown in Table 1, there is a total of 122.169 Malaysians who have been declared bankrupt from the year 2007 to 2013, and alarmingly the percentage rate of bankruptcy increased by year.

Table 1

Number of Malaysians Declared Bankrupt from 2007 to 2013

\begin{tabular}{ll|ll}
\hline Years & Total (People) & Years & Total (People) \\
\hline 2007 & 13.238 & 2011 & 19.167 \\
2008 & 13.855 & 2012 & 19.575 \\
2009 & 16,228 & 2013 & 21.987 \\
2010 & 18.119 & & \\
\hline Total & & \\
\hline
\end{tabular}

Table 2 depicts the percentage of Malaysians who are declared bankrupt by age from year 2007 to 2013. The young generation is ranked the third highest age group from the list of bankruptcies among Malaysians, which is shown at 20.1\%. This shows that Malaysians have been burdened with debt and bankruptcies from the young age. It will have a negative impact on economic development and would threaten the equilibrium of life of Malaysians in the future, if this issue is not well taken care of.

Table 2

Rate of Bankruptcy by Age from 2007 to 2013

\begin{tabular}{ll|ll}
\hline Age (Years) & Percentage (\%) & Age (Years) & Percentage (\%) \\
\hline $25-34$ & 20.09 & 55 and above & 11.77 \\
$35-44$ & 34.31 & Others & 7.34 \\
$45-54$ & 26.49 & & \\
\hline
\end{tabular}

Source: Berita Harian newspaper dated September 16, 2014

Based on the statistics, it showed that the young generation are among the highest age group that have fallen in the critical problems of this bankruptcy issue. Hence, it is highly noted that the issue of bankruptcy should not be underestimated, notably for young people in Malaysia. Notwithstanding, the individual's attitude of over spending would affect his or her literacy and behaviour towards finance leading to the state of poor financial planning which has currently become the main difficulty in addressing this issue.

The young generation inclusive of the student group must have adequate financial knowledge in order to make the best possible financial decision on saving, investment and daily expenses. 
Those without, will eventually lead to poor financial management, which consequently will affect student's academic performance, mental health condition and physical well-being. Financially, illiterate persons have tendency to adopt welfare-reducing choices due to their lack of knowledge (Albeerdy \& Gharleghi, 2015).

Many research have been conducted worldwide to measure the level of financial literacy whereby the results concluded that there are seriously poor level of financial literacy among the communities. Regardless of that, according to Sekar and Gowri (2015), there is still lack of research and concrete judgement that has been concluded on financial literacy. Hence, this study focuses on financial literacy among the young generation. The objective of this research is to examine the determinants of financial literacy and its impact on financial decision by level of education.

\section{The Financial Literacy}

Financial literacy is defined as the people's capability to process the economic particulars and make informed decisions on financial planning, wealth accumulation, debt, and pensions ( Lusardi \& Mitchell, 2014). According to the study of Noctor Stoney and Strandling (1992, as cited in I. Albeerdy \& Gharleghi, 2015), the financial literacy is concluded as the preparedness of an individual to make informed judgments and to take constructive decisions on the usage and management of money. The financial literacy helps a person to manage the surplus and deficit of money, especially among the young generations to make financial decisions for better future planning and to consider saving for their retirement days.

Being financially literate signifies that a person would benefit from a palette of abilities and attitudes such as understanding of money management concept, recognition of financial institutions and attitudes which enable effective and responsible management of financial matters as previously studied by Schagen and Lines (1996, as cited in Albeerdy \& Gharleghi, 2015). Financial literacy is one of the components in human capital that can be used to increase the expected lifetime utility from consumption in financial activities, for example behaviours that strengthen financial well-being (Huston, 2010). Thus, it affects the human decision on financial. This study is also supported by other authors of previous studies which mentioned that financial literacy affects the financial decision-making; ignorance on basic financial concepts can be linked to lack of retirement planning, lack of participation in the stock market, and poor borrowing behaviour (Lusardi, 2008). Literacy consists of understanding matters such as knowledge of words, symbols and arithmetic operations and uses that ability to read, write and calculate of materials related to prose, document and quantitative information (Huston, 2010).

There are many discussions that categorized individuals with higher savings as the people who plan for their retirement due to their financial awareness. In this sense financial awareness provides the abilities to make more rational financial choice and decisions, which lead to higher welfare at the end. This argument has been well documented in the United State of America, where private savings decisions for retirement are particularly germane. Based on this information, the studies were extended to other countries by Lusardi and Mitchell (2014), Bucher-Koenen and Lusardi (2011). 
Policymakers generally emphasized the importance of personal finance education in school as well as later in life which as mentioned by Bernake speech (as cited in Sozou, 2016). Financial education supports not only the individual well-being but also the economic health of our nation. As the recent financial crisis illustrated, consumers who can make informed choices about financial products and services not only serve their best interests, but collectively, they also help promote broader economic stability. Smart financial planning such as controlling the budget, saving money for emergencies, and preparing for retirement can help many households to enjoy better lives even facing financial shocks. Financial education can play a powerful role in getting to overcome these situations. Based on the previous studies, it can be seen that financial literacy can influence an individual in making the financial choices. Knowledge, skills, educational background, act, and environments affect the financial choices.

\section{Behaviour}

According to Mendes (2013), in order to make a suitable individual financial decision, it can be concluded that financial literacy is more than just a simple assessment of knowledge, reflecting a set of behaviour and skill. Besides that, Robb, Babiarz, and Woodyard (2012) mentioned that actions taken by each individual is the reflection of the individual financial well-being, apart from influence from the external factors. That is why it is considered a critical importance of the apprehending relationship between knowledge and personal financial issue. As Bordon, Lee, Serido, and Collins (2008) stated there is no significant connection between financial awareness and effective financial act. Besides that, other research also showed that if an individual learns to pick up consumer behaviour during their old age, it will contribute a strong influence towards the person (Lusardi \& Mitchell, 2014).

According to Mahdzan and Tabiani (2013, as cited in Hinga, 2012), a positive attitude in an individual saving behaviour is shown by the people who save more frequently, as opposed to those who do not save. The probability of having a positive saving attitude is significantly related to the saving regularity. As an example, the act of setting aside a portion of the income as saving would most likely to lead to higher probability of having positive saving attitude.

In sum, many past studies have examined the relationship between financial literacy and behaviour in college students. As Greene (2014) and Baker, Bettinger, Jacob, and Marinescu (2018) examined the relationship between financial literacy and financial act and found that an increase in financial awareness which engage in a positive financial behaviour of an individual.

\section{Parental Factor}

Awareness and closeness define parental factor method. A study conducted by Kim and Jang (2014) found that parental support and influence lead to better self-esteem and lower tendency to be obsessed by materialism amongst the young generations. Clarke et al. (2005) and Brown et al. (1993) mentioned that financial literacy can be influenced by parents teaching and showing good examples to their children from the young age. This would make the influence to be more than peer influence on understanding the financial issues. According to Jorgensen (2007), parenting style has significant influence on their children's awareness, attitudes, and financial behaviour. Moreover, as Mandell (2008, as cited in Ani, Kelmara, \& Guilherma, 2015) noted parents' education level is also one of the factors that determine the financial 
literacy of individuals. In addition to that, other studies also proved that if children learn consumer act from their parents, it can strongly influence their spending behaviour. According to Cohen and Nelson (2011) and Ramsey (2004), children learn the basic of financial literacy and adapt themselves how to spend money wisely from the examples shown in their homes.

In their study, Bucciol and Veronesi (2014) found that if children are suggested to save money from their parents, it will increase the willingness to save about $16 \%$. The encouragement from the parents will nurture good habit in the children's behaviour. Besides that, according to Firmansyah (2014), children inherit the attitude and behaviour from their family and this can predict the kind of financial decisions and management that they will decide in the future. On the contrary, Padilla-Walker, Nelson, and Carroll (2012) found that parental factors may lead to financial stability and independence in the children's monetary aspects.

\section{Peer Influence}

According to the research of Bristol and Mangleburg (2004, as cited in Noor Zaihan, 2016), peer influence is defined by the degree to which peers affect person's state of mind, thinking and behaviour. Interestingly, a study by Jamal, Ramlan, Karim, and Osman (2015) proved that peers' influence has a critical part in deciding the student's savings ability. Noor Zaihan (2016) found that despite the fact that the parents or guardians have formed positive financial behaviour in their children, peer socialization angle still exist in children's saving's behaviour since saving behaviour of students could be influenced by association in spending exercises during social time and exchanging ideas about financial management matters among their peers. According to Jamal, Ramlan, Karim, and Osman (2015), it is stated that peer influence could also affect persons' financial behaviour. Alwi, Amir Hashim, and Ali (2015) stated that Generation $\mathrm{Y}$ is always influenced by peer force when making any decisions. Moreover, Laible Carlo, and Roesch (2004) stated that youngster's behaviour is acquired from direct and indirect interaction with their friends. Besides that, Ogonowski, Montandon, Botha, and Reyneke (2014) also mentioned that social influence with closer peers has the most important influence in the forming the bad or good attitude of Gen Y in terms of physical and social distance. On top of that, Amer Azan and Abdul Jamal (2015) also agreed that besides parenting factors, peer pressure could also affect individuals' financial behaviour. As stated in the study of "Household debts are self-inflicted" (2013), it was said that in Malaysia, the most noticeable cause that ruined the youngsters in managing their finances was because of peer influence.

\section{Theory/Financial Socialization: A Conceptual Model}

In this study, the theory that is used based on the previous studies is financial socialization on conceptual model. This theory explained that the children's behaviours are transferred from their parents. According to Cho, Gutter, Kim, and Mauldin (2012), socialization agents include youth's parents, communities, teachers and media (Van Campenhout, 2015). Lusardi and Mitchell (2014) mentioned that youth are able to financially socialize outside their family. High school financial education instructors can be the primary financial socialization agent as observed by Nguyen and Benet-Martínez (2013). 


\section{Social Capital Theory}

Social capital theory is derived from interpersonal resources which stated that the positive relationship between the younger generation with their parents have strong relational ties with youthful community, and peer support, as concluded by Nguyen and Benet-Martínez (2013). There is a positive impact on education performance when children and parent spent time together (Nguyen \& Benet-Martínez, 2013). This theory also explained that youth with the higher social trust always like to share their ideas with other persons, according to Avery (as cited in Nguyen \& Benet-Martínez, 2013). The youth's financial knowledge and awareness is lower if the resources are less accessible (Huang, Nam, \& Sherraden, 2013).

\section{Theoretical Framework}

The theoretical framework is a set of theoretical concept that explains the researcher's assertion on how a certain issues and factors are associated and related to each other (Sekaran \& Bougie, 2013). Besides, it also enables the researcher to unfold the knowledge by exploring the validity of the theory through the various analysis tests of the independent and dependent variables according to the proposed theoretical framework. The theoretical framework of this research based on the literature review is illustrated in Figure 1 below.

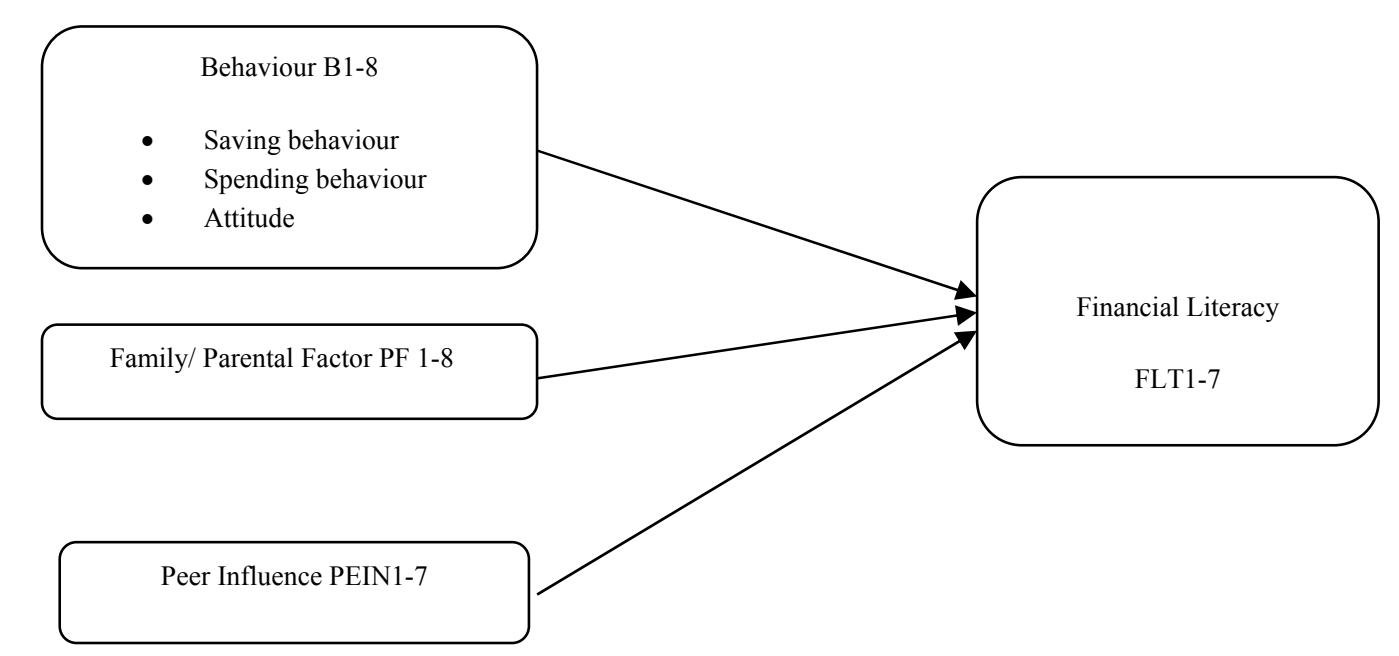

Figure 1. Theoretical framework

Figure 1 shows the proposed theoretical framework for this research, which was modified to fit into the objective of this research. Based on the above proposed theoretical framework, the demographic factors, acts, parental factor as well as peer influence were chosen as the independent difference while the dependent difference was the financial literacy. Therefore, four independent variables were used in order to examine their relationship with the dependent variable, which was financial literacy.

\section{Hypotheses Development}

$\mathrm{H}_{1}$ : There is a relationship between behaviour and financial literacy.

$\mathrm{H}_{2}$ : There is a relationship between Family/Parental factor and financial literacy.

$\mathrm{H}_{3}$ : There is a relationship between peer influence and financial literacy. 


\section{Method}

\section{Research Design}

In order to meet the objectives of this research, the most appropriate research strategy using quantitative approach was chosen. It was expedited through distributing self-administrated questionnaire to the respondents. This research design is supported by a study conducted by Sekaran and Bougie (2013); they mentioned that the main reason of using the quantitative approach is usually because it is generally inexpensive and time consuming compared to the other study strategies. Other than that, Bhatti, Hoe and Sundram (2012) asserted that the survey research is the most favoured method of the data collection in the quantitative approach and many researchers used this method as it allocates possibility for more truth and unequivocal responses or feedback than the other forms of research methodologies. Moreover, most of the self-administered questionnaires will be kept confidential. Hence, Sekaran and Bougie (2013) also stated that the anonymity of the respondents would be high and almost $100 \%$ of respond rate is almost ensured. Furthermore, this study is explanatory or descriptive research. Since the researcher is interested in studying the determinant factors of financial literacy among the young generation, the descriptive study is designed to reveal the relationship between the variables (Sekaran \& Bougie, 2013). Additionally, the descriptive study also enables the researcher to think systematically about the factors that might influence the financial literacy among young generations and offer critical ideas for further research.

Next, the time horizon that has been applied in this study is the cross-sectional studies. It is because the data that has been collected for this study was gathered within a week in order to meet the requirement of data collection. Nonetheless, the unit of analysis can be expressed as respondents were directly involved in responding to the data collection. The appropriate unit of analysis for the study were the individuals who took part in this data collection among the young generation from the state of Kedah, Perlis, Perak, Johor and Kuala Lumpur.

\section{Population and Sample of Study}

Population refers the total number of people, events or things that the researcher wants to examine the common characteristic required by the researcher (Sekaran \& Bougie, 2013). This study aims to study the determinant factor of financial literacy among the young generation in certain states in Malaysia. The population of interest of this research is among the young generation in the state of Kedah, Perlis, Perak, Johor and Kuala Lumpur. The targeted population for this research is focused on the youthful generation between the age of 18 to 34 years old. According to Etikan, Musa and Alkassim (2016), a sample is a subset containing the characteristics of a larger demographic. A sample should represent the whole population and not reflect bias towards a specific attribute. Further to that, the estimated sample size of this study is 500 respondents in the sample stage.

\section{Sampling Technique}

For the specimen technique, this study used convenience sampling method. The convenience sampling is a non-probability sampling technique where subjects are selected because of their convenient accessibility and proximity to the study (Etikan et al., 2016). The subjects in this 
study were selected just because they were easy to recruit for the study. However, the researcher did not consider selecting subjects who represented the entire population. Etikan et al., (2016) stated that the convenience samples are sometimes considered as 'accidental samples' because the respondents may be chosen in the sample simply due to the fact that they just happen to be located near to where the researcher is performing the data collection.

In general, it would be best to examine the entire population such as conducting census study, but in most cases, the population to be studied is just too large and it is unmanageable to include every single person to participate in the study (Given, 2008). This is the reason why most of the times researchers depend on sampling method like convenience sampling, which is the most commonly used of all sampling techniques. Many researchers choose this sampling technique because it is fast, easy, less expensive, and the materials to conduct the study on are readily available.

\section{Unit of Analysis}

Unit of analysis is defined as one of the objects of study within a research project. This paper adopted Partial Least Squares Structural Equation Modelling (PLS-SEM). According to Cole (2017), the most common units of analysis are individuals, groups, social interactions, organizations and institutions, social and cultural artifacts. In many cases, a study or research can require multiple units of analysis (Cole, 2017). The unit of analysis of this study is individual who belongs to the young generation group. The role of this study was to get an overall view of the financial literacy among young generations in the state of Kedah, Perlis, Perak, Johor and Kuala Lumpur.

\section{Data Collection}

Both primary and secondary sources are considered important in order to provide the information related to this research. Hence, this research sought for data from secondary sources like various journals, literatures and articles. Apart from that, the primary sources were also used to collect the data and facts related to the research by using self-administered questionnaires. In this research, the self-administered questionnaires were randomly distributed to the young generation, targeted especially for Generation Y (Gen Y) who were still studying and working on this project. The researcher had approached the respondents from the state of Kedah, Perlis, Perak, Johor and Kuala Lumpur so that the data collected are easily gathered based on the disproportionate stratified sampling.

\section{Results}

\section{Measurement Model}

The measurement model as shown in Table 3 (Construct Convergent Validity and Reliability) and in Figure 2 can be assessed through convergent validity and discriminant validity. Hair, Black, Babin, Anderson (2010) refer to convergent validity as the degree to which a place of construct meets in measuring the concept on the construct (Hair et al., 2010). As Table 1 shows, the AVE values between .39 to .49 and the Compesite Reliability CR values of the constructs above the recommended assessment of .7, which ranges between .77 to .82 it, can be established that measurement model has a sufficient degree of convergent validity. 
Table 3

Construct Convergent Validity and Reliability

\begin{tabular}{|c|c|c|c|c|c|}
\hline Variable & İtems & Factor loadings & Cronbachs Alpha & $\begin{array}{l}\text { Compesite } \\
\text { Reliability } \\
\end{array}$ & AVE \\
\hline \multirow{4}{*}{ Behaviour B } & B1 & .73 & \multirow{4}{*}{.62} & \multirow{4}{*}{.77} & \multirow{4}{*}{.46} \\
\hline & B2 & .77 & & & \\
\hline & B3 & .64 & & & \\
\hline & B8 & .58 & & & \\
\hline \multirow{7}{*}{ Family/Parental PF } & PF1 & .60 & \multirow{7}{*}{.74} & \multirow{7}{*}{.82} & \multirow{7}{*}{.39} \\
\hline & PF2 & .60 & & & \\
\hline & PF3 & .58 & & & \\
\hline & PF4 & .66 & & & \\
\hline & PF5 & .59 & & & \\
\hline & PF6 & .68 & & & \\
\hline & PF7 & .66 & & & \\
\hline \multirow{5}{*}{ Financial Literacy FLT } & FLT1 & .56 & \multirow{5}{*}{.74} & \multirow{5}{*}{.82} & \multirow{5}{*}{.49} \\
\hline & FLT2 & .62 & & & \\
\hline & FLT3 & .80 & & & \\
\hline & FLT4 & .79 & & & \\
\hline & FLT5 & .68 & & & \\
\hline \multirow{5}{*}{ Peer Influence PEIN } & PEIN2 & .70 & \multirow{5}{*}{.74} & \multirow{5}{*}{.82} & \multirow{5}{*}{.48} \\
\hline & PEIN3 & .74 & & & \\
\hline & PEIN5 & .74 & & & \\
\hline & PEIN6 & .87 & & & \\
\hline & PEIN7 & .60 & & & \\
\hline
\end{tabular}

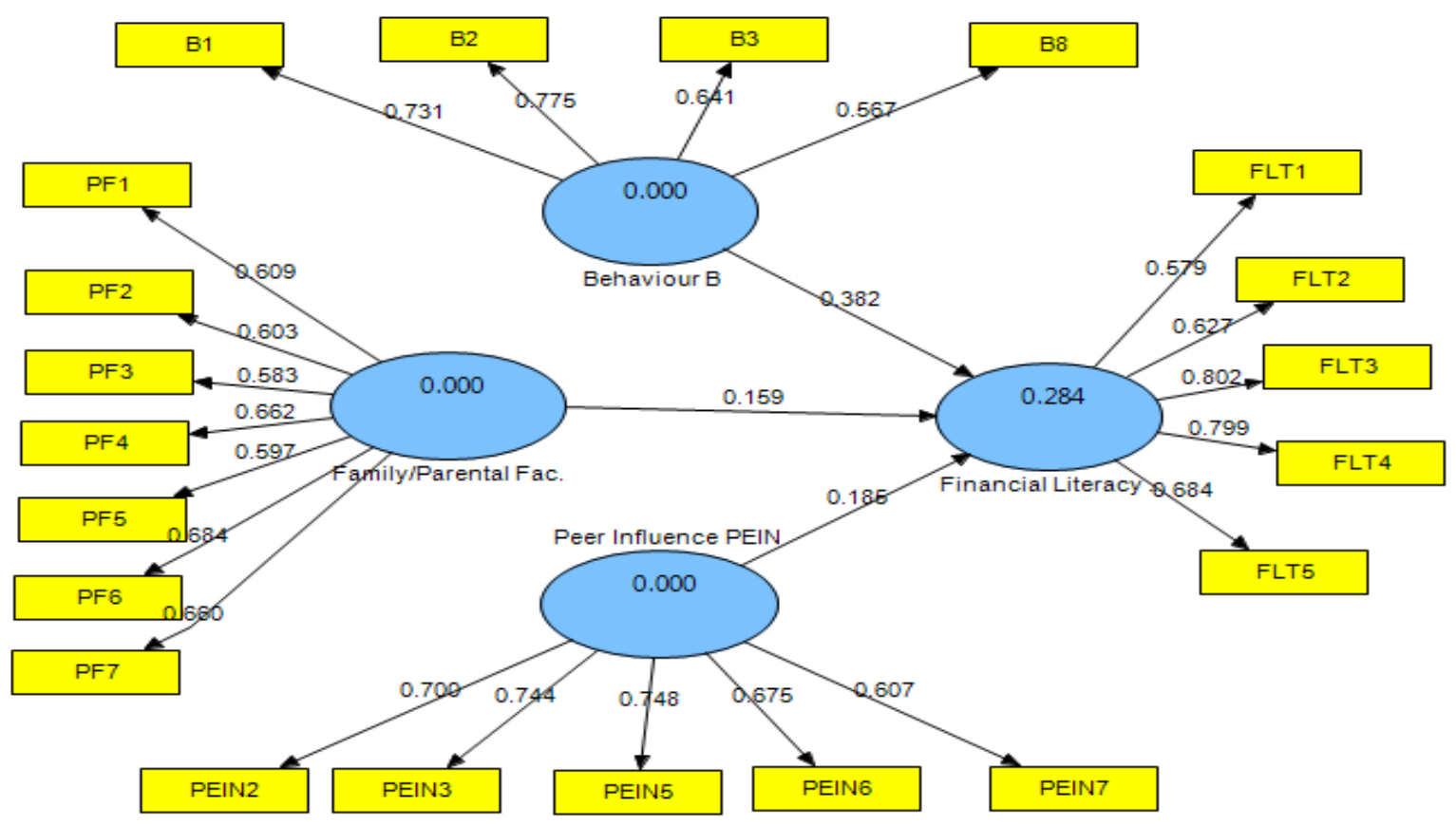

Figure 2. Measurement model

As presented in Table 4 and Figure 2, the R2/Square value indicated that all the study variables including $\mathrm{ABC}$ Implementation, and Organizational Performance OP are capable of influencing $.28 \%$ of the changes in the dependent variable which is the performance.

Table 4

$R$ Square 
Behaviour B

Family/Parental PF

Financial Literacy FLT

Peer Influence PEIN

\section{Structural Model/ Hypothesise Model}

After a careful assessment of the measurement model in Figure 1, then the structural model for this study was examined as shown in Figure 3. Hair et al., (2006) viewed Structural model as a model that expresses about the reliance of association in the hypothesized model. In terms of path coefficient, partial least squares, as argued by Hair et al., (2012), is just like the standardized beta coefficient in regression analysis. The fundamental objective of structural model is to test the hypothesized relationships among constructs. The structural model evaluation continues with an examination of the direct relationship.

Table 5 and Figure 3 illustrate three of the results of direct relationships between contingency variables (H1 Behaviour B, H2 Family/Parental PF and H3 Peer Influence PEIN) and Financial Literacy FLT. The three hypothesized relationships between contingency varaibles and Financial Literacy FLT indicate significant and positive relationships. These paths include (1) H1 Behaviour B $->$ Financial Literacy FLT; $(\beta=.38 ; t=8.81 ; p<.001)$; (2) H2 Family/Parental PF $->$ Financial Literacy FLT $(\beta=.15 ; t=3.48 ; p<.001) ;(3)$ H3 Peer Influence PEIN $->$ Financial Literacy FLT $(\beta=.18 ; t=4.69 ; p<.001)$.

Table 5

Result of Hypothesis Testing

\begin{tabular}{llllll}
\hline & $\begin{array}{l}\text { Original Sample } \\
(\mathrm{O}) \beta \text { Beta }\end{array}$ & $\begin{array}{l}\text { Standard } \\
\text { Error }\end{array}$ & $t$ & $p$ & Decision \\
\hline H1 Behaviour B -> Financial Literacy FLT & .38 & .04 & 8.81 & .001 & Supported \\
H2 Family/Parental PF -> Financial Literacy FLT & .15 & .04 & 3.48 & .001 & Supported \\
H3 Peer Influence PEIN -> Financial Literacy FLT & .18 & .03 & 4.69 & .001 & Supported \\
\hline
\end{tabular}

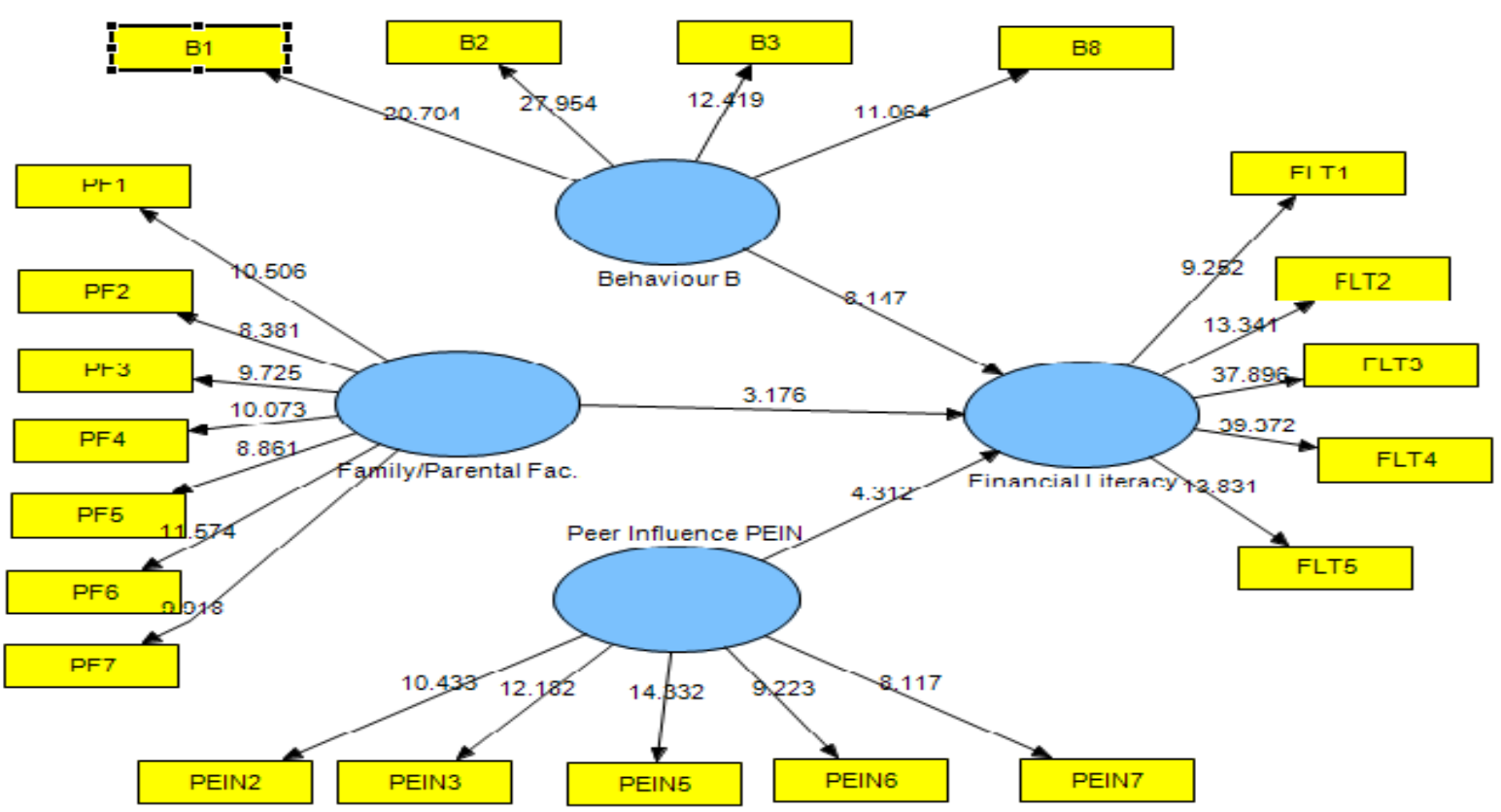

Figure 3. Structural model/ Hypothesise model 
As presented in Table 5, all the study hypotheses were accepted and possess a t-value of greater than 1.96 which shows an adequate support for the three direct hypotheses.

\section{Discussion and Conclusion}

The discussion of the study basically focused on the research objectives of this study. Research objectives focus on finding the influence of Behaviour B, Family/Parental PF , and Peer Influence PEIN on Financial Literacy FLT, Family/Parental PF and Peer Influence PEIN of Yung genration in Malaysia. The findings of this study revealed that Behaviour B, Family/Parental PF, and Peer Influence PEIN among Young genration in Malaysia is significantly related to Financial Literacy FLT. The results revealed a positive relationship between (Behavior B, Family/Parental PF, and Peer Influence) and financial literacy. The findings related to Behavior, Family/Parental, Peer Influence and Financial Literacy were supported by Borden, Lee, Serido, and Collins (2008), Robb et al. (2012), and Murugiah (2016). Consequently, the result is consistent with the researcher's expectation that there a noticeable and a significant positive relationship between Behavior, Family/Parental PF, and Peer Influence and the financial literacy. In addition, the findings revealed a significant positive relationship between Family/Parental factor and financial literacy as explained by Jorgensen (2007). The results also showed a positive relationship between peer influence and financial with financial literacy. The peer influence was found to be statistically important and positively related to the financial literacy. Ogonowski et al. (2014) stated that Generation Y (Gen Y) is always influenced by peer force during decision-making. They also mentioned that social influence with closer peers have the most important influence on the bad or good attitude of Gen $\mathrm{Y}$ in terms of physical and social distance.

\section{Contribution and Implication of the Study Theoretical Contribution}

From a theoretical position, the impact of the study lies in determining the influence of population factors, behaviour, parental factor, peer influence and financial fulfilment towards financial literacy. Currently there is a very limited study that underlines the financial literacy especially in Malaysia. Hence, this study underwrites to the literature by investigating the influence of the determinant factors towards financial literacy.

\section{Policy Implication}

The results of this study give some implications to the public. The findings confirm that the feelings of impossibility in regard to their future goals lead to reduction on financial literacy level. Due to this, parents should know their vital role in the financial life of their children and should take more powerful role in strengthening their children's spending habit and teach the value of financial education.

Following that, the findings from the research also provide important data to the academicians and university administrators, where they should pay more attention to provide additional education chances for students. They are suggested to prepare and conduct actual courses, seminar, workshop and other financial programs based on the needs and the student's 
level of financial literacy. Hence, it would be able to give advantage to the students on making practical decisions on their finance and at the same time could increase their financial literacy.

The results of the study are also important for policy makers mainly the government. The ruling government is recommended to play their role in presenting the event of "Financial Literacy Month" in Malaysia. The aim of the event is to highlight the importance of financial literacy and provide the knowledge on how to start and continue the financial habits among the society. Moreover, it is highly recommended that the government to introduce the financial literacy programs in primary and secondary schools all over Malaysia. The need to present financial literacy at an early stage is essential so that the society can undertake greater accountability for their financial health since young age.

Furthermore, this study also gives suggestion for the government to look into providing more financial courses and education in Malaysia in view of growing anxieties over rising debts in youth in the country recently.

Finally, it is also suggested the financial advisor and planner to have better understanding of the current situation in financial literacy. The findings provided the knowledge on the factors that had more impact towards financial literacy; therefore, the advisors and planners could identify their customer's interests and notice their customer's personal problems releted to the financial issues.

\section{Recommendations for Future Research}

The study was limited to only Kedah, Perlis, Perak, Johor and Kuala Lumpur in Malaysia and the respondents were restricted to 18 years old until 35 years old only. Moreover, further research needs to be conducted using a survey research on other states in Malaysia.

Hence, in order to generalise the results and have more reliable and accurate findings, a more capacious study should be carried out in the future with wider sample. Besides, the researcher faced difficulty in searching for journals and articles to support the research due to the inadequate sources and very limited study done on this subject; thus, more future studies related to financial literacy need to be carried out.

Finally, a qualitative study needs to be conducted for future research to replicate the findings as the judgments about the levels of financial literacy of individuals conducted in this research. It is further hoped that the study can enlarge the awareness in the related fields and can be a benchmark for financial literacy research in Malaysia.

\section{References}

Alwi, S., Amir Hashim, I. Z., \& Ali, M. S. (2015, August). Factors affecting savings habits within millennials in malaysia: Case study on students of Taylor's university. Proceedings of the Fourth Asia-Pacific Conference on Global Business, Economics, Finance and Social Sciences, 1-10. www. globalbizresearch. org.

Jamal, A. A. A., Ramlan, W. K., Karim, M. A., \& Osman, Z. (2015). The effects of social influence and financial literacy on savings behavior: A study on students of higher learning institutions in Kota Kinabalu, Sabah. International Journal of Business and Social Science, 6(11), 110-119.

Baker, R., Bettinger, E., Jacob, B., \& Marinescu, I. (2018). The effect of labor market information on community college students' major choice. Economics of Education Review. http://www.nber.org/papers/w23333

Bucciol, A., \& Veronesi, M. (2014). Teaching children to save: What is the best strategy for lifetime savings? Journal of Economic Psychology, 45, 1-17. 
Bhatti, M. A., Hoe, C. H., \& Sundram, V. P. K. (2012). A guide for beginners data analysis using SPSS and AMOS. kuala lumpur, malaysia: Pearson Malaysia Sdn.

Bucher-Koenen, T., \& Lusardi, A. (2011). Financial literacy and retirement planning in Germany. Journal of Pension Economics and Finance, 10(4), 565-584.

Borden, L. M., Lee, S. A., Serido, J., \& Collins, D. (2008). Changing college students' financial knowledge, attitudes, and behavior through seminar participation. Journal of family and economic issues, 29(1), 23-40.

Cohen, M., \& Nelson, C. (2011). Financial literacy: A step for clients towards financial inclusion. Global Microcredit Summit, $14-17$.

Cole, N. (2017). Units of Analysis. Retrieved march 24, 2017, from https://www.thoughtco.com/wh-units-of-analysis-matter4019028

Cho, S. H., Gutter, M., Kim, J., \& Mauldin, T. (2012). The effect of socialization and information source on financial management behaviors among low-and moderate-income adults. Family and Consumer Sciences Research Journal, 40(4), $417-430$.

Firmansyah, D. (2014). the influence of family background towards student's saving behaviour: A Survey of College Students in Jabodetabek. International Journal of Scientific and Research Publications, 4(1), 1-6.

Given, L. M. (Ed.). (2008). The Sage encyclopedia of qualitative research methods. Thousand Oaks: Sage Publications.

Greene, R. H. (2014). How financial literacy influences long-and short-term financial behaviors in different age cohorts (Unpublished doctoral dissertation). University of Georgia, United State of America.

Hair, J., Black, J. W., Babin, B. J., \& Anderson, R. E. (2010). Multivariate data analysis. United State of America: Pearson Prentice Hall.

Hair, J. F., Jr., Black, W. C., Babin, B. J., Andersen, R. E., \& Tatham, R. L. (2006). Mutilvariate data analysis (6th ed.). Upper Saddle River, NJ: Pearson Prentice Hall.

Hair, J. F., Sarstedt, M., Pieper, T. M., \& Ringle, C. M. (2012). The use of partial least squares structural equation modelling in strategic management research: A review of past practices and recommendations for future applications. Long Range Planning, 45(5/6), 320-340.

Huang, J., Nam, Y., \& Sherraden, M. S. (2013). Financial knowledge and child development account policy: A test of financial capability. Journal of Consumer Affairs, 47(1), 1-26.

Hinga, G. K. (2012). Relationship of financial literacy on individual savings of employees of postal corporation of Kenya based in Nairobi (Unpublished doctoral dissertation). University of Nairobi, Kenya.

Albeerdy, M. I., \& Gharleghi, B. (2015). Determinants of the financial literacy among college students in Malaysia. International Journal of Business Administration, 6(3), 15-24.

Idris, F. H., Krishnan, K. S. D., \& Azmi, N. (2013). Relationship between financial literacy and financial distress among youths in Malaysia - An empirical study. Malaysian Journal of Society and Space, 9(4), 106-117.

Etikan, I., Musa, S. A., \& Alkassim, R. S. (2016). Comparison of convenience sampling and purposive sampling. American Journal of Theoretical and Applied Statistics, 5(1), 1-4.

Jamal, A. A. A., Ramlan, W. K., Karim, M. A., \& Osman, Z. (2015). The effects of social influence and financial literacy on savings behavior: A study on students of higher learning institutions in Kota Kinabalu, Sabah. International Journal of Business and Social Science, 6(11), 110-119.

Huston, S. J. (2010). Measuring financial literacy. The Journal of ConsumerAffairs, 44(2), 296-316.

Jorgensen, B. L. (2007). Finanial literacy of college students: Parental and peer influence. Virginia: Blacksburg.

Kim, D., \& Jang, S. S. (2014). Motivational drivers for status consumption: A study of Generation Y consumers. International Journal of Hospitality Management, 38, 39-47.

Laible, D. J., Carlo, G., \& Roesch, S. C. (2004). Pathways to self-esteem in late adolescence: The role of parent and peer attachment, empathy, and social behaviours. Journal of adolescence, 27(6), 703-716.

Lusardi, A. (2008). Financial literacy: An essential tool for informed consumer choice? National Bureau of Economic Research, Working Paper No. 14084. Retrieved from http://www.nber.org/papers/w14084

Lusardi, A., \& Mitchell, O. S. (2014). The economic importance of financial literacy: Theory and evidence. Journal of Economic Literature, 52(1), 5-44.

Mendes, A. F. (2013). Financial Literacy of College Students - Study Case: Students of the University of Porto (Unpublished master's thesis). University of Porto, Portugal. 
Murugiah, L. (2016). The level of understanding and strategies to enhance financial literacy among Malaysian. International Journal of Economics and Financial Issues, 6(3S), 130-139.

Nguyen, A. M. D., \& Benet-Martínez, V. (2013). Biculturalism and adjustment: A meta-analysis. Journal of Cross-Cultural Psychology, 44(1), 122-159.

Noor Zaihan, D. (2016). Determinants of saving behavior among generation Y students in Universiti Utara Malaysia (Unpublished doctoral dissertation). Universiti Utara Malaysia, Malaysia.

Ogonowski, A., Montandon, A., Botha, E., \& Reyneke, M. (2014). Should new online stores invest in social presence elements? The effect of social presence on initial trust formation. Journal of Retailing and Consumer Services, 21(4), 482491.

Padilla-Walker, L. M., Nelson, L. J., \& Carroll, J. S. (2012). Affording emerging adulthood: Parental financial assistance of their college-aged children. Journal of Adult Development, 19(1), 50-58.

Peeters, N., Rijk, K., Soetens, B., Storms, B., \& Hermans, K. (2018). A Systematic Literature Review to Identify Successful Elements for Financial Education and Counseling in Groups. Journal of Consumer Affairs, 52(2), 415-440.

Ramsey, P. G. (2004). Teaching and learning in a diverse world: Multicultural education for young children (Vol. 93). Teachers College Press: New York.

Remund, D. L. (2010). Financial literacy explicated: The case for a clearer definition in an increasingly complex economy. The Journal Of Consumer Affairs, 44(2), 276-295.

Robb, C. A., Babiarz, P., \& Woodyard, A. (2012). The demand for financial professional's advice: The role of financial knowledge, satisfaction, and confidence. Financial Service Review, 292-295.

Sekar, M., \& Gowri, M. (2015). A study on financial literacy and its determinants among generation Y employees in Coimbatore city. Great Lakes Herald, 9(1), 35-45. BIBLIOGRAPHY

Sekaran, U., \& Bougie, R. (2013). Research methods for business a skill building approach. United Kingdom: John Wiley \& Sons Ltd.

Sozou, G. (2016). Hunting for Financial Literacy (Master's thesis). Retreieved from https://academicworks.cuny.edu/hc_sas_etds/37

BIBLIOGRAPHY Van Campenhout, G. (2015). Revaluing the role of parents as financial socialization agents in youth financial literacy programs. Journal of Consumer Affairs, 49(1), 186-222. 